University of Vermont

UVM ScholarWorks

Rubenstein School of Environment and Natural Rubenstein School of Environment and Natural Resources Faculty Publications

$1-1-2012$

\title{
Biogenic vs. geologic carbon emissions and forest biomass energy production
}

John S. Gunn

Manomet Center for Conservation Sciences Brunswick

David J. Ganz

Lowering Emissions in Asia's Forests (LEAF)

William S. Keeton

University of Vermont

Follow this and additional works at: https://scholarworks.uvm.edu/rsfac

Part of the Agriculture Commons, Climate Commons, and the Sustainability Commons

\section{Recommended Citation}

Gunn JS, Ganz DJ, Keeton WS. Biogenic vs. geologic carbon emissions and forest biomass energy production. Gcb Bioenergy. 2012 May;4(3):239-42.

This Article is brought to you for free and open access by the Rubenstein School of Environment and Natural Resources at UVM ScholarWorks. It has been accepted for inclusion in Rubenstein School of Environment and Natural Resources Faculty Publications by an authorized administrator of UVM ScholarWorks. For more information, please contact scholarworks@uvm.edu. 


\title{
OP I N I O N
}

\section{Biogenic vs. geologic carbon emissions and forest biomass energy production}

\author{
JOHN S. GUNN*, DAVID J. GANZ† and WILLIAM S. KEETON \\ *Natural Capital Initiative, Manomet Center for Conservation Sciences, 14 Maine St., Suite 410, Brunswick, ME, 04011, USA, \\ $\nmid$ Lowering Emissions in Asia's Forests (LEAF), Liberty Square, Suite 2002287 Silom Road Bang Rak, Bangkok, 10500, Thailand, \\ $\$$ The Rubenstein School of Environment and Natural Resources, University of Vermont, 209 Hills Building, 81 Carrigan Drive, \\ Burlington, VT, 05405, USA
}

\begin{abstract}
In the current debate over the $\mathrm{CO}_{2}$ emissions implications of switching from fossil fuel energy sources to include a substantial amount of woody biomass energy, many scientists and policy makers hold the view that emissions from the two sources should not be equated. Their rationale is that the combustion or decay of woody biomass is simply part of the global cycle of biogenic carbon and does not increase the amount of carbon in circulation. This view is frequently presented as justification to implement policies that encourage the substitution of fossil fuel energy sources with biomass. We present the opinion that this is an inappropriate conceptual basis to assess the atmospheric greenhouse gas (GHG) accounting of woody biomass energy generation. While there are many other environmental, social, and economic reasons to move to woody biomass energy, we argue that the inferred benefits of biogenic emissions over fossil fuel emissions should be reconsidered.
\end{abstract}

Keywords: bioenergy emissions, biogenic carbon, carbon debt, forest biomass, greenhouse gas accounting

Received 20 April 2011; revised version received 14 July 2011 and accepted 3 August 2011

A recent letter to US House of Representatives Natural Resource and Energy and Commerce Committees signed by more than 100 academics from American universities articulated a concern over equating biogenic carbon (C) emissions with fossil fuel emissions in emerging state and federal legislation and rule making (Lippke et al., 2010). They stated that 'the combustion or decay of woody biomass is part of the global cycle of biogenic carbon and does not increase the amount of carbon in circulation. In contrast, carbon dioxide released from fossil fuels increases the amount of carbon in the cycle'. This view recently has been reiterated by many (e.g. Hale, 2010; Lucier, 2010; Strauch et al., 2010; Sedjo, 2011) as justification to promote policies that encourage the substitution of fossil fuel energy sources with biomass. This position ignores the inherent complexities associated with atmospheric greenhouse gas (GHG) accounting of woody biomass energy generation, including the consideration of the system boundaries used in net emissions calculations and the indirect effects associated with land-use change. According to some calculations, switching from fossil fuels to wood energy could actually result in increased levels of

Correspondence: John S. Gunn, tel. + 207721 9040,

fax + 207721 9144, e-mail: jgunn@manomet.org atmospheric GHGs, at least over a period of decades (e.g. Searchinger et al., 2009; Walker et al., 2010; McKechnie et al., 2011). This recent scientific approach to the issue has come about through the recognition by many in the scientific community that GHG accounting must consider explicitly the carbon dynamics of the woody biomass feedstock source and not dismiss it as immediately 'carbon neutral.' Though our comments below are driven by the US policy debate over how to treat biomass energy emissions, this desire to dismiss these important biogenic emissions is echoed internationally. In particular, the current Intergovernmental Panel on Climate Change (IPCC, 2006) GHG accounting approach accounts for feedstock carbon stock change, but does not attribute biogenic emissions to the energy sector. This approach risks creating incentives for bioenergy production that, in some circumstances, may emit more $\mathrm{CO}_{2}$ than the fossil fuel alternatives over the whole life cycle of the bioenergy chain and considering indirect pay-back effects (Bird et al., 2011).

There are many credible environmental, social and economic reasons to move away from fossil fuels, including: reducing dependence on foreign petroleum, providing economic incentives to maintain forest management infrastructure, and encouraging conservation of working forests. But for the specific goal of mitigating 
climate change, the critical question to answer is 'what will the atmosphere see and over what timescale?' as a result of switching from geologic to biogenic fuel sources. The physics of the greenhouse effect is indifferent as to the origin of the pollutant. Once a molecule of $\mathrm{CO}_{2}$ is in the atmosphere its heating capacity is the same regardless of its source. It is the overall $\mathrm{C}$ budget and the net atmospheric concentration of greenhouses gases that are of concern. If greater use of wood energy has the unintended consequence of contributing to an increase in atmospheric $\mathrm{CO}_{2}$ concentrations, then decisions to switch to biogenic fuels should be guided by careful accounting to determine net carbon fluxes to and from the atmosphere.

An earlier letter to the US House of Representatives and US Senate (Schlesinger et al., 2010) from 90 American scientists stated that 'Although fossil fuel emissions are reduced or eliminated, the combustion of biomass replaces fossil emissions with its own emissions (which may even be higher per unit of energy because of the lower energy to carbon ratio of biomass)'. More research is needed to determine which biomass energy technology scenarios and forest ecosystems are most likely to result in greater biogenic emissions than the equivalent fossil fuel energy source. But recent work in the United States and Europe supports the Schlesinger et al. (2010) statement (e.g. Walker et al., 2010; Bird et al., 2011; McKechnie et al., 2011). In addition, if biomass harvests involve living trees that would otherwise have remained alive and growing, the short-term net impact on the atmosphere will be greater than if logging residue or waste wood were used. All wood is not equal in terms of temporal impact to atmospheric GHG levels. Therefore, the use of wood for energy needs a strong quantitative basis ensuring policy based on evidence rather than opinion.

Wood energy harvests encompass a wide range of silvicultural treatments, but have the potential to increase the overall intensity and frequency of harvesting. This can reduce the net amount of carbon stored in forest biomass at any moment in time at landscape scales, particularly in natural forest systems with low risk of catastrophic disturbances and relatively slow growth rates. If overall harvesting intensity increases to meet new demand for wood energy, carbon stocks on the landscape can be depressed to a lower equilibrium storage condition therefore increasing overall atmospheric $\mathrm{CO}_{2}$ even when considering the substitution benefits (Harmon et al., 1990; Smithwick et al., 2006; McKechnie et al., 2011). In addition, when biomass energy is produced from land converted to nonforest uses; regrowth of forests and the associated uptake of $\mathrm{C}$ will not occur. As long as the world continues to experience net loss of forest cover (deforestation) and harvest intensity increases, the residence time period for biogenic $C$ in the atmosphere is likely longer than what is assumed by many scientists. Moreover, most sequestration of this biogenic $C$ in the atmosphere will likely occur beyond the critical timeframe for addressing climate change (e.g. the next 50 years). When we also consider the amount of biogenic $C$ remaining in the atmosphere as a result of historical global conversion of forests, prairies, peatlands and wetlands (Birdsey et al., 2006; Rhemtulla et al., 2009; van der Werf et al., 2009), it becomes clear that all sources of additional $\mathrm{C}$ emissions should be evaluated based upon their near term contribution to the atmosphere and their potential for re-sequestration by new biological growth. This historical debt also negates the argument that biogenic carbon can be banked in advance of consumption for energy (e.g. Sedjo, 2011). Again, what matters is the amount of $\mathrm{CO}_{2}$ in the atmosphere, regardless of the source.

One rationale for increasing the use of forest biomass for energy is that the biogenic carbon cycle is in balance as long as trees are growing and sequestering carbon somewhere else within other forests (Lucier, 2010). While this argument makes sense when considering the sustained yield of wood products, it fails to consider the complete basis for calculating net GHG effect on the atmosphere of switching from fossil fuels to biomass. Moreover, when applied to carbon, this approach implies that the biogenic carbon cycle is separate from a global carbon cycle. It is indisputable that emissions from fossil fuels contribute to the atmospheric pool by releasing carbon from the geologic pool and are therefore new emissions to the atmosphere. However, the same is functionally true, in terms of climate implications, for any biological carbon emission with a low likelihood or a delayed return ( $>50$ years) to the biogenic or oceanic pools. If alternatives to fossil fuels include use of forests where $\mathrm{C}$ is emitted and resides in the atmosphere for long periods of time (e.g. decades or longer), a reduction of atmospheric concentrations of $\mathrm{CO}_{2}$ (e.g. to 350 ppm; Hansen et al., 2008) will be difficult to achieve and may contribute to some degree of irreversible climate change (Solomon et al., 2009). With this in mind, we must continue to ask ourselves whether we are truly using forests to their greatest atmospheric benefit.

What matters most in our climate change mitigation efforts is the movement of $\mathrm{C}$ from any pool into and out of the atmosphere (i.e. the net effect on atmospheric carbon concentrations). Consider the five major global pools of $\mathrm{C}$ in decreasing order of volume: oceanic; geologic; pedologic; atmospheric; and biogenic (Morgan et al., 2010). The flow of C among these pools operates at varying temporal scales. It may take millions of years for $C$ to move from the biogenic pool 
to the geologic pool, while fluxes between the atmospheric and biogenic pools are continuous. Humans influence movement among pools by burning fossil fuels and releasing $\mathrm{C}$ to the atmospheric pool. Likewise, we burn and clear forests from the biogenic pool to convert land to agriculture, development, and other nonforest uses, leading essentially in many cases to a permanent loss of biogenic C (van der Werf et al., 2009; Hansen et al., 2010). Movement of biogenic C from the atmosphere back into the biogenic pool cannot be automatically assumed. Biogenic C released from activities such as permanent deforestation, or the combustion of forest biomass for energy, must be replaced through photosynthesis and sequestration to maintain flow from the atmosphere back into the biogenic pool. In the context of climate change mitigation efforts, activities that generate emissions from biogenic or geologic $\mathrm{C}$ pools should be evaluated for the contribution it makes to the atmospheric pool and the timing of residence.

There is an immediate need to deal with the complexity of carbon accounting as it relates to woodderived bioenergy. Scientists are studying the benefits and tradeoffs associated with different carbon management scenarios in a variety of forest types around the world (Harmon \& Marks, 2002; Seidl et al., 2007; Mitchell et al., 2009; North et al., 2009; Swanson, 2009; Hurteau et al., 2010; Nunery \& Keeton, 2010; Gunn et al., 2011). As our understanding of this complexity improves, we need to carefully consider the role of forests as both a potential C sink and source (Ray et al., 2009). If forests are going to be used to reduce our dependence on fossil fuels, we will need to determine where and when to provide the economic incentives to maintain the forest management infrastructure and our working forests. Independently verified sustainable forestry standards that conserve our forest resources in perpetuity provide one existing mechanism to prevent degradation and promote forest practices with $\mathrm{C}$ sequestration benefits. The opportunities to use our forests and maintain them as forests with their embedded ecosystem service values is worthy of balancing the carbon accounting issues mentioned here with the other management objectives (water, biodiversity, human livelihoods, recreation, energy, etc.). Ideally, balancing the flow of ecosystem service values from forests will benefit from global policies such as Reducing Emissions from Deforestation and Forest Degradation (REDD) that consider the whole suite of ecosystem goods and services including atmospheric benefits (Canadell \& Raupach, 2008; Ebeling \& Yasue, 2008; FAO UNDP, 2008). But first, we must be confident that our climate policies designed to reduce atmospheric GHGs in a time frame that matters actu- ally do reduce GHG levels, and not unwittingly increase them.

\section{References}

Bird DN, Zanchi G, Pena N, Havlík P, Frieden D (2011) Analysis of the Potential of Sustainable Forest-Based Bioenergy for Climate Change Mitigation, Working Paper No. 59, CIFOR, Bogor, Indonesia.

Birdsey R, Pregitzer K, Lucier A (2006) Forest Carbon Management in the United States: 1600-2100. Journal of Environmental Quality, 35, 1461-1469.

Canadell JG, Raupach MR (2008) Managing forests for climate change mitigation. Science, 320, 1456-1457.

Ebeling J, Yasue M (2008) Generating carbon finance through avoided deforestation and its potential to create climatic, conservation and human development benefits. Philosophical Transactions of the Royal Society B, 363, 1917-1924.

FAO UNDP (2008) UN-REDD: UN Collaborative Programme on Reducing Emissions from Deforestation and Forest Degradation in Developing Countries (UN-REDD). FAO, UNDP, UNEP Framework Document. Available at: http://www.un-redd.org/ Publications/tabid/587/Default.aspx (accessed 7 September 2011).

Gunn JS, Saah D, Fernholz K, Ganz D (2011) Carbon credit eligibility under area regulation of harvest levels in Northern Minnesota. Forest Science, (in press).

Hale R (2010) American Forest \& Paper Association Comments on Massachusetts Department of Energy Resources (DOER) Manomet Biomass Sustainability and Carbon Policy Study, Carbon Accounting and Biomass/RPS Policy Directions, August 12, 2010. Available at: http://www.mass.gov/Eoeea/docs/ doer/renewables/biomass/study comments/American\%20Forest $\% 20 \& \% 20$ Paper \%20Association,\%20Rhea\%20Hale.pdf (accessed 20 April 2011).

Hansen J, Sato M, Kharecha P et al. (2008) Target atmospheric $\mathrm{CO}_{2}$ : where should humanity aim? Open Atmospheric Science Journal, 2, 217-231.

Hansen MC, Stehman SV, Potapov PV (2010) Quantification of global gross forest cover loss. Proceedings of the National Academy of Sciences USA, 107, 8650-8655.

Harmon ME, Marks B (2002) Effects of silvicultural practices on carbon stores in Douglas-fir-western hemlock forests in the Pacific Northwest, USA: results from a simulation model. Canadian Journal of Forest Research, 32, 863-877.

Harmon ME, Ferrell WK, Franklin JF (1990) Effects on carbon storage of conversion of old-growth forests to young forests. Science, 247, 699-702.

Hurteau MD, Stoddard MT, Fule PZ (2010) The carbon costs of mitigating high-severity wildfire in southwestern ponderosa pine. Global Change Biology, 17, $1516-1521$

IPCC (2006) 2006 IPCC Guidelines for National Greenhouse Gas Inventories, Prepared by the National Greenhouse Gas Inventories Programme (eds Eggleston HS, Buendia L, Miwa K, Ngara T, Tanabe K), IGES, Japan.

Lippke B, Oneil E, Winistorfer PM et al. (2010) Letter to US House of Representatives Energy \& Commerce Committee and US House of Representatives Natural Resource Committee, 20 July 2010.

Lucier A (2010) A Fatal Flaw in Manomet's Biomass Study. The Forestry Source, 15, p. 4.

McKechnie J, Colombo S, Chen J, Mabee W, MacLean HL (2011) Forest bioenergy or forest carbon? Assessing trade-offs in greenhouse gas mitigation with woodbased fuels. Environmental Science \& Technology, 45, 789-795.

Mitchell SR, Harmon ME, O'Connell KEB (2009) Forest fuel reduction alters fire severity and long-term carbon storage in three Pacific Northwest ecosystems. Ecological Applications, 19, 643-655.

Morgan JA, Follett RF, Allen LH Jr (2010) Carbon sequestration in agricultural lands of the United States. Journal of Soil and Water Conservation, 65, 6A-13A.

North M, Hurteau M, Innes J (2009) Fire suppression and fuels treatment effects on mixed-conifer carbon stocks and emissions. Ecological Applications, 19, 1385 1396.

Nunery JS, Keeton WS (2010) Forest carbon storage in the northeastern United States: net effects of harvesting frequency, post-harvest retention, and wood products. Forest Ecology and Management, 259, 1363-1375.

Ray DG, Seymour RS, Scott NS, Keeton WS (2009) Mitigating climate change with managed forests: balancing expectations, opportunity, and risk. Journal of Forestry, $107,50-51$.

Rhemtulla J, Mladenoff D, Clayton M (2009) Historical forest baselines reveal potential for continued carbon sequestration. Proceedings of the National Academy of Sciences USA, 106, 6082-6087.

Schlesinger WH, Allen M, Aneja VP et al. (2010) Letter to Nancy Pelosi, US House of Representatives and Harry Reid, US Senate 17 May 2010. 
242 J. S. GUNN et al.

Searchinger T, Hamburg SP, Melillo J et al. (2009) Fixing a critical climate accounting error. Science, 326, 527-528.

Sedjo RA (2011) Carbon Neutrality and Bioenergy: A Zero-Sum Game? Resources for the Future Discussion Paper DP 11-15. Available at: http://www.rff.org/RFF/ Documents/RFF-DP-11-15.pdf (accessed 14 July 2011).

Seidl R, Rammer W, Jager D, Currie WS, Lexer MJ (2007) Assessing trade-offs between carbon sequestration and timber production within a framework of multi-purpose forestry in Austria. Forest Ecology and Management, 248, 64-79.

Smithwick EAH, Harmon ME, Domingo JB (2006) Changing temporal patterns of forest carbon stores and net ecosystem carbon balance: the stand to landscape transformation. Landscape Ecology, 22, 77-94.

Solomon S, Plattner GK, Knuttic R, Friedlingstein P (2009) Irreversible climate change due to carbon dioxide emissions. Proceedings of the National Academy of Sciences, 106, 1704-1709.
Strauch P, Payne JN, Cleaves B (2010) Maine Voices: Tale of the Tree Turns a New Leaf, Portland Press Herald, September 5, Op-Ed. Available at: http://www.pressherald. com/opinion/tale-of-the-tree-turns-a-new-leaf_2010-09-05.html (accessed 19 April 2011).

Swanson ME (2009) Modeling the effects of alternative management strategies on forest carbon in the Nothofagus forests of Tierra del Fuego, Chile. Forest Ecology and Management, 257, 1740-1750.

Walker T, Cardellichio P, Colnes A et al. (2010) Biomass Sustainability and Carbon Policy Study. Manomet Center for Conservation Sciences. NCI-2010-03. 189 pp. Available at: http://www.manomet.org/sites/manomet.org/files/Manomet_Biomass_ Report_Full_LoRez.pdf (accessed 19 April 2011).

van der Werf GR, Morton DC, DeFries RS et al. (2009) $\mathrm{CO}_{2}$ emissions from forest loss. Nature Geoscience, 2, 737-738. 